\title{
The Mediation Role of Implementation in Retirement Policy and Welfare of Retired Clergy in Buganda Dioceses of Church of Uganda
}

Paul Kakooza ${ }^{1 *}$, Wilson Muyinda Mande ${ }^{2}$

\author{
${ }^{1}$ School of Social Sciences Nkumba University P O Box 237 Entebbe Uganda \\ ${ }^{2}$ Nkumba University P O Box 237 Entebbe Uganda
}

DOI: $10.36347 /$ sjahss.2021.v09i04.003

| Received: 23.02.2021 | Accepted: 10.04.2021 | Published: 18.04.2021

*Corresponding author: Paul Kakooza

Abstract

Original Research Article

The cardinal task of this study was to analyse the mediation role of implementation in the Church of Uganda (COU) retirement policy and the welfare of retired clergy in Buganda Dioceses. In spite of COU's introducing a retirement policy in 2010, with the objective of promoting welfare among the retired clergy, evidence revealed that Church of Uganda retired clergy were writhing under very low conditions of welfare. Finding revealed that implementation approaches of the dioceses mediated only $13 \%$ of the relationship between retirement policy and welfare of the retired clergy. In view of this analysis, the study proposed a central approach to retirement policy implementation instead of leaving it to each diocese to figure out is own approach.

Key words: Retirement policy implementation, welfare, retired clergy.

Copyright $(\mathcal{C} 2021$ The Author(s): This is an open-access article distributed under the terms of the Creative Commons Attribution 4.0 International License (CC BY-NC 4.0) which permits unrestricted use, distribution, and reproduction in any medium for non-commercial use provided the original author and source are credited.

\section{INTRODUCTION}

This study set to analyse retirement policy implementation and welfare of retired clergy in Buganda dioceses. Church of Uganda (COU) formulated retirement policy in 2010 with the following objectives;

1) To ensure welfare of COU clergy even after they have retired from active ministry by providing benefits like pension and gratuity upon one's retirement.

2) To provide relief for COU staffs' dependents in events of a staff's death and of such other or ancillary benefits as a secured to staff under the rules.

3) To provide annuity and life assurance benefits stipulated by the policy for both lay staff and clergy.

4) To ensure good corporate governance and to comply with the state's statutory obligation of every employing institution.

5) To attract and retain competent and skilled workforce to the church through incentives like retirement benefits (Church of Uganda Financial Policies and Procedures Manual 2016; Church of Uganda Provincial Human Resource policy Manual, 2009).

This study therefore intended to analyse the mediation role of implementation in the retirement policy and welfare of retired clergy. A retirement policy is a framework which is intended to regulate the income of the employees who leave the service of an institution and separate from the institution after reaching a certain age [1]. In COU the retirement age is 65 years. For many employers, there must be a policy requiring them to put in place a scheme under which the staff can receive some income when they have finally left work.

The COU became independent form the Church of England in 1961. COU was no longer under the tutelage of the Church of England. In the succeeding years, the missionary clergy gradually retired from the COU and were replaced by Ugandans [3]. In 1953 COU put in place a provident Fund scheme. Under this scheme, clergy men were to contribute $5 \%$ of their monthly stipend to the fund. The Church would match that with the same amount [2]. However since the contributions were not forthcoming as expected the Church was forced to design another scheme.

The retirement policy of the COU in the 1970 stated that, it was to commence operation in January 1972 [4]. Under this, the Church employee would qualify for the benefits if he was of 65 years. Since the money was being paid into National Insurance Corporation, the money received under the scheme was administered by the headquarters of the Province of the COU. In 1975, the COU formulated a retirement 
scheme which constituted a retirement policy for clergy at all levels of priest, bishop and archbishop [4].The retirement policy was necessitated by the absence of policy to cater for the welfare of retiring clergy.

A trust deed was completed and stated that "the annuity and life assurance benefits provided for, under the scheme shall be secured by a Master Policy or policies affected by National Insurance Corporation by the trustees who shall hold the benefits thereafter upon trust for the purpose of the scheme" [4]. It is clear that retirement policy was made by trustees.

The Dioceses in Buganda area embarked on developing their own retirement programs to support the wellbeing of retiring clergy. The dioceses in Buganda region were required to implement the provincial retirement policy [5-7]. The retirement policy and the ensuing practices were intended to promote the welfare of retired clergy in the Dioceses.

\section{Statement of the problem}

Church of Uganda's retirement policy was formulated so that each diocese could implement it in a way that would promote the welfare of it's the retired clergy. So the implementation approach was important in that this was the only way the welfare of the retired clergy could guaranteed. However, the implementation may not enable the retirement policy to bring about the required welfare. This view is based on the observations of several observers Mbabazize [8], Ntagali [9] and Bukenya and Ebitu [10]. Since each diocese used its own approach, the Dioceses of Mukono, Luweero, Namirembe, Mityana and West Buganda offer pension ranging between UGX50000 to UGX150000. These are paid quarterly or annual implying that beneficiaries do not get monthly payments $[11,12,13,7]$. This has raised many serious questions on the welfare of the retired clergy. This has been summed up by Kazimba [14] who contended that Church of Uganda clergy serve honorably and retire miserably. It is clear that the problem this study seeks to solve is the mediation role of implementation between retirement policy and welfare of the clergy

\section{OBJECTIVES}

1.1 To analyse the relationship between retirement policy and implementation approaches adopted by Buganda dioceses.

1.2 To assess the effect of implementation approaches on the welfare of retired clergy in Buganda dioceses.

1.3 To analyse the contribution of the retirement policy on the welfare of the retired clergy in Buganda dioceses.

1.4 To assess the mediation role of the implementation approaches in retirement policy and welfare of retired clergy in Buganda dioceses.

\section{LITERATURE REVIEW AND HYPOTHESES} Retirement policy and implementation strategies

A retirement policy improves the quality of the retirees' welfare. For that matter, a retirement policy entails measures that can facilitate improvement in overall quality of retirees' life after facing a general drop in their pay [15]. This is a truism which calls for contestation.

On one hand some there are authors who focus on health after retirement. They argue that health decline during older age is considered a normal consequence of aging [16-18]. The above thesis is not espoused by all researchers on retirement policy. For instance, Asakawa \& Senthilselvan [19] contend that aging does not have to result into decrease in functional capacities or health-related quality of life, especially in the young-old (that is to say aged about 55-75 years). Furthermore, other studies suggest a steady decrease in self-assessed health in populations at middle age [20]. From a meta-analysis of the relationship between age and workers' health, $\mathrm{Ng} \&$ Feldman [21] found a modest decline in clinical indicators of physical health in older e-workers (for instance, blood pressure, cholesterol, and body mass index). The implication of the aforementioned facts about health during old age is that although health status can naturally decline due to the ageing process, it can still be upheld if managed or if appropriate health care is sought. De Nardi, et al. [12]; Kopecky \& Koreshkova [23] suggested that medical expenses are an important source of old-age and retirement impoverishment, since most retirees often have no adequate savings. Many have no insurance policies to enable them afford out of pocket expenditure on quality health services.

Although this is a good debate, it does not cover the question of how much does diocesan implementation mediate the relationship between retirement policy and the welfare of the retired clergy of Church of Uganda in Buganda ecclesiastical jurisdiction. This is the primary question that the current study seeks to provide answer to.

\section{Implementation and welfare}

On the issue of implementation of policy and the welfare of the clergy, some authors [24] have argued that sound retirement policy should not only focus on health hazards rather it must entail key provisions that address general welfare needs. The policy ought to explicitly pronounce itself on the range of realistic employee terminal benefits, occupational health and safety, social and psychosocial guidance, rights and responsibilities, insurance guidelines and other tenets. So, a robust retirement policy in order to ensure the welfare of the retirees.

Other researchers [25, 26] emphasized the need to plan for the psychosocial adversity like work 
stress in midlife, anxiety, loneliness and mental wellbeing. The extent to which exposures during employment many of which are amenable to intervention have predictive value beyond retirement has not been established. Nonetheless, there is some evidence that social inequalities in physical health, indexed as self-rated general health [25]. Mental wellbeing is deemed to persist after retirement and should be upheld or else stress at work predicts poorer post retirement mental and physical well-being [27]. The notion is in agreement with those who contend that transition to retirement is detrimental to mental health, there are several potential mechanisms through which retirement may have adverse impact on mental health, above and beyond the immediate reduction in income. It is further argued that the social role theory posits that retirement results in the loss of many non-financial benefits of work $[28,29]$. The opportunities for healthpromoting social contacts and access to social support that can buffer the adverse effects of stress [30, 31]. Activity theory also postulates that the transition to retirement results in reduced wellbeing for individuals for whom work provided meaning in life [32]. Moreover, the impact of retirement on mental health may not be universal and could vary between individuals depending on his occupational class or social situation (for example the presence of social support in the home environment from a marital partner) $[33,34]$. Thus implying that retirement needs exceed monitory supplies.

The above debate about the implementation and welfare throw more light on the subject of welfare. However, there debate does not include the retirees of not for profit organisation like the Anglican Church of Uganda. Furthermore, the studies involved in that above debate, did not consider mediation. Mediation analysis is the cardinal task of the current study.

\section{RESEARCH METHODOLOGY} are given

In this section, an explanation of the following

\section{Population and sample}

The population of the current was drawn from retired clergy in the dioceses of Buganda. The numbers that constituted the sample of the study were as follows:

Table-1: Anglican dioceses in Buganda

\begin{tabular}{|l|l|l|l|}
\hline \multicolumn{2}{|l|}{ Diocese } & Number of retirees & percentage \\
\hline 1 & Namirembe diocese & 12 & 12.8 \\
\hline 2 & West Buganda diocese & 9 & 9.6 \\
\hline 3 & Kampala diocese & 12 & 12.8 \\
\hline 4 & Mityana diocese & 26 & 27.7 \\
\hline 5 & Mukono diocese & 22 & 23.4 \\
\hline 6 & Luwero diocese & 13 & 13.8 \\
\hline \multicolumn{2}{|l|}{ Total } & 94 & 100.0 \\
\hline
\end{tabular}

As it is given in Table 1 retired clergy from six dioceses were included in this study. Central Buganda diocese was not included. As far as Anglican ecclesiastical jurisdiction in Buganda region was concerned, about $86 \%$ was covered by the study. The percentage of $86 \%$ was high enough to draw credible conclusion.

The sample of 94 was in line with Roscoe's [35] assertion that in social science research any sample between 30 and 500 can produce credible results

\section{Data collection from the field}

Data collection was done by means of a questionnaire which was distributed and filled by the retired clergy in the six dioceses. The self-administered questionnaire had 69 items. Of these, 8 were on nominal scale while the remaining 61 were on a fivepoint Likert scale of $1=$ strongly disagree, 2 = disagree, $3=$ neutral, $4=$ agree and $5=$ strongly agree. The questionnaire was the main tool for data collection. This tool was in line with the survey method which was deemed the most appropriate for the study.

\section{Justification of the mediation analysis}

The mediation model was adopted for this study because the cardinal intention was to understand the causal role of the diocesan approaches to implementation of the policy. The retirement policy was the same but each diocese took its own approach of implementing in the respective diocese. This reason justified the use of the mediation model. In other words the mediation sought to answer the question: did the implementation approaches of the dioceses mediate the relationship between the retirement policy and the welfare of the retired clergy? The mediation model is as given in figure 1 .

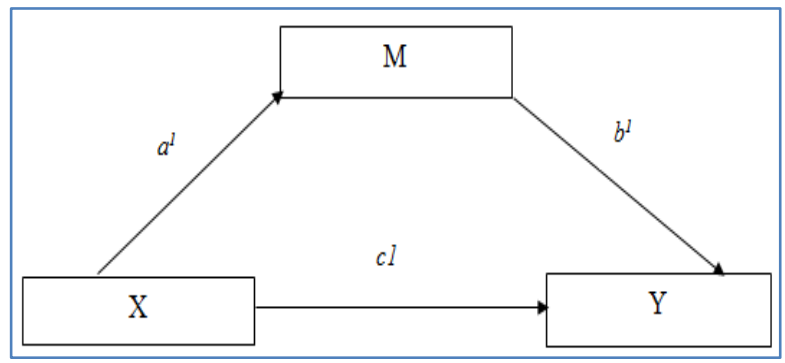

Fig-1: The mediation model 
The mediation model was adopted so that a mediation analysis of the diocesan implementation could be done. In the model, $\mathrm{X}$ is the independent variable, the $\mathrm{M}$ is the mediator variable, and $\mathrm{Y}$ is the outcome variable. The slope $\mathrm{a}^{1}$ represents the effect of IV on MV; the slope $b^{1}$ represents the effect of MV on $\mathrm{DV}$; and $\mathrm{c} 1$ represents the direct effect of the IV on the DV.

\section{DATA ANALYSIS}

The mediation analysis in this study data was done using the PROCESS of Andrew Hayes version 3.5 in the Statistical Package for the Social Sciences (SPSS) Version 20.0

The hypotheses for mediation

Table-2: Hypotheses associated with mediation

\begin{tabular}{|l|l|}
\hline Hypothesis & Statement of the hypothesis \\
\hline H1 & $\begin{array}{l}\text { The effect of } \mathrm{X} \text { on M } \\
\text { That is, the relationship between Retirement Policy and Implementation is significant and positive. }\end{array}$ \\
\hline H2 & $\begin{array}{l}\text { The effect of M on Y } \\
\text { That is, the effect of implementation on welfare is significant and positive }\end{array}$ \\
\hline H3 & $\begin{array}{l}\text { M mediates the relationship between X and Y } \\
\text { That is, Implementation mediates the relationship between retirement policy and welfare of retired clergy }\end{array}$ \\
\hline
\end{tabular}

The hypotheses were developed using the segmentation approach. This approach was deemed appropriate because there were several hypotheses [36]. In that way $\mathrm{HI}$ which is coterminous with the independent variable $(\mathrm{X})$ effects the mediator (M). In $\mathrm{H} 2$ which is the mediator variable effects the dependent or outcome variable (Y). The H3 is where $\mathrm{M}$ mediates the relationship between $\mathrm{X}$ and $\mathrm{Y}$.

\section{RESEARCH FINDINGS \\ Mediation analysis model}

Retirement policy was intended to effect welfare of retired clergy. Hence the illustration given in figure 2 .

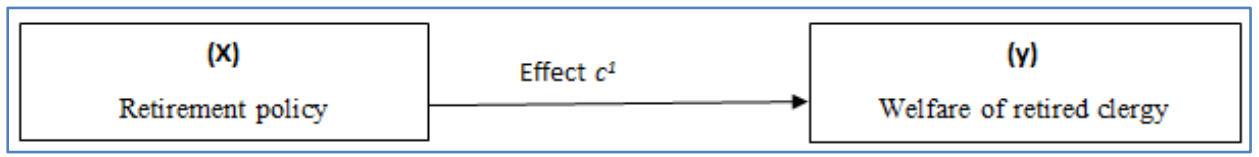

Fig-2: Direct effect of $X$ on $Y$

It is important to note that retirement policy (X) qua retirement policy (X) could not effect that welfare without being implemented, hence the mediator variable (M) referred to as implementation. This is illustrated in figure 3 .

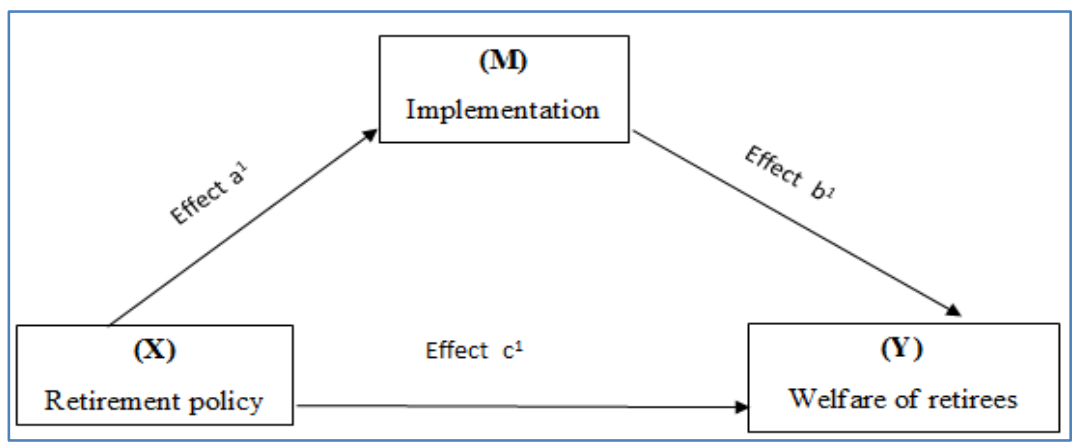

Fig-3: Completed mediation model

To obtain the mediation (also known as indirect effect) it necessitates doing the multiplication of slope $\left(a^{1}\right)$ by slope $\left(b^{1}\right)$ or $a^{1} \times b^{1}$. The direct effect is $c^{1}$. The total direct effect could be derived by adding the indirect effect with the direct one, or $c=a^{1} \mathrm{x} \mathrm{b}^{1}+\mathrm{c}^{1}$.

\section{Confirmation of the mediation effect}

Prior to execution of mediation analysis, it is important to first determine whether there is significant relationship among the variables. That is, is there a relationship between the independent variable $(\mathrm{X})$ and the dependent variable (Y) through the mediator variable $(\mathrm{M})$ ?

To do the confirmation, the following three steps must be followed: 
Step 1: confirm whether there is a significant relationship between $\mathrm{X}$ and $\mathrm{Y}$, that is, between retirement policy and welfare of retired clergy. This step is important because if there is no positive significant relationship between the two variables then, there is nothing to mediate. For the current study the formula was $\mathrm{Y}=\mathrm{bo}+\mathrm{b} 1 \mathrm{X}+\mathrm{e}$. The SPSS linear regression yielded the following results in table 4 .

Table-3: Whether relationship between $X$ and $Y$ were significant

\begin{tabular}{|l|l|l|l|l|l|l|}
\hline Predictor (X) vs dependent (Y) & $\mathbf{N}$ & $\mathbf{R}^{\mathbf{2}}$ & Std error & Beta & t & p \\
\hline Retirement policy vs welfare of retirees & 94 & .207 & 109 & .464 & 5.031 & .000 \\
\hline
\end{tabular}

The results in table 3 indicate that the sample was 94 retirees. The retirement policy explained $21 \%$ of the welfare. T-value was 5.031 which was greater than 1.96. It was two-tailed; and had the p-value significance at $\mathrm{p}<0.01$. It can be concluded that there was a positive and significant relationship between retirement policy and welfare of retired clergy.

Step 2: confirm whether $X$ effects $M$, that is, is there a relationship between retirement policy (X) and implementation (M). This had to be confirmed because if retirement policy had no positive significant relationship with implementation, then, mediation would be uncalled for. In this study, the formula applied was $\mathrm{M}=\mathrm{bo}+\mathrm{b} 2 \mathrm{X}+\mathrm{e}$ was used to determine the effect of retirement policy on implementation. The SPSS linear regression computation gave the following results in Table 4:

Table-4: Results of the effect of $X$ on $M$

\begin{tabular}{|l|l|l|l|l|l|l|}
\hline Predictor (X) vs dependent (M) & $\mathbf{N}$ & $\mathbf{R}^{\mathbf{2}}$ & Std error & Beta & $\mathbf{t}$ & $\mathbf{p}$ \\
\hline Retirement policy vs implementation & 94 & .154 & .074 & .404 & 4.237 & .000 \\
\hline
\end{tabular}

In table 4 , the regression results clearly show that the sample was 94 retirees in Buganda dioceses were the ones who participated in the current study as respondents. Retirement policy (X) explained $15 \%$ of implementation. The t-value was 4.237 which was greater than the $\mathrm{z}$ - score of 1.96. The level of significance was at $\mathrm{p}<0.01$ which left only less than $1 \%$ probability. From all this, it can be inferred that retirement policy $(\mathrm{X})$ had significant effect on the implementation (M).

Step 3. Confirms whether $M$ affects $Y$, that is, whether implementation affects welfare of retired clergy in Buganda Anglican dioceses. It also follows that if $\mathrm{M}$ affects $\mathrm{Y}$, then retirement policy (X) no longer has effect on welfare (Y). In SPSS the results yielded were as stated in table 5:

Table-5: Results of the effect of $M$ on $Y$

\begin{tabular}{|l|l|l|l|l|l|l|}
\hline Predictor (M) vs dependent (Y) & $\mathbf{N}$ & $\mathbf{R}^{2}$ & Std error & Beta & $\mathbf{t}$ & $\mathbf{p}$ \\
\hline implementation vs welfare of retirees & 94 & .338 & .077 & .588 & 6.970 & .000 \\
\hline
\end{tabular}

The regression results in table 5 indicate that respondents were 94 retirees in Buganda Anglican dioceses. Implementation (M) explained $34 \%$ of welfare. The $\mathrm{t}$-value was high, that is, 6.970. This like the others was greater than the $\mathrm{z}-$ score of 1.96 . The level of significance was at $\mathrm{p}<0.01$ which left only less than $1 \%$ probability. From all this inference is that implementation (M) had significant effect on welfare (Y) of retirees.

The primary purpose of the above steps $1-3$ was to establish that zero-order relationships among the variables existed. Since all relationships are positive and significant, it is appropriate to infer that mediation was possible.

\section{Mediation analysis Using PROCESS procedure}

For the current study, the PROCESS procedure version 3.5 for SPSS of Andrew F Hayes was used with bootstrapping to carry out the mediation. The following were the results.

\section{Model: 4}

$$
\begin{array}{cl}
\text { Y : welfc } & \text { (Welfare of retired clergy) } \\
\text { X : Retpol } & \text { (retirement policy) } \\
\text { M : polimp } & \text { (implementation) } \\
\text { Sample } & \\
\text { Size: } 94 &
\end{array}
$$

Sample

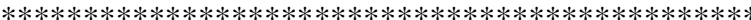


OUTCOME VARIABLE:

polimp

Model Summary

$\begin{array}{ccccccc}\mathrm{R} & \mathrm{R}-\mathrm{sq} & \mathrm{MSE} & \mathrm{F} & \mathrm{df} 1 & \mathrm{~d} 2 & \mathrm{p}\end{array}$

Model

$\begin{array}{lllllll}.4645 & .2157 & .6014 & 25.3079 & 1.0000 & 92.0000 & .0000\end{array}$

\begin{tabular}{|c|c|c|c|c|c|c|}
\hline & coeff & se & t & $\mathrm{n}$ & LJ CI & \\
\hline Constant & 1.6835 & .2902 & 5.8007 & .0000 & 1.1071 & 2.2599 \\
\hline Retpol & .5480 & .1089 & 5.0307 & .0000 & .3317 & .7643 \\
\hline
\end{tabular}

\section{XOUTCOME VARIABLE:}

welfc

Model Summary

\begin{tabular}{|c|c|c|c|c|c|c|}
\hline & $\begin{array}{c}\mathrm{R} \\
.6062\end{array}$ & $\begin{array}{r}\text { R-sq } \\
.3675\end{array}$ & $\begin{array}{l}\text { MSE } \\
.2945\end{array}$ & $\begin{array}{c}\mathrm{F} \\
6.4334\end{array}$ & $\begin{array}{c}\mathrm{df1} \\
2.0000\end{array}$ & $\begin{array}{cc}\mathrm{df} 2 & \mathrm{p} \\
91.0000 & .0000\end{array}$ \\
\hline Model & & & & & & \\
\hline & coeff & se & $\mathrm{t}$ & $\mathrm{p}$ & LLCI & ULCI \\
\hline Constant & 1.5176 & .2374 & 6.3934 & .0000 & 1.0461 & 1.9890 \\
\hline Retpol & .4666 & .0861 & 5.4202 & .0000 & .2956 & .6376 \\
\hline polimp & .1295 & .0730 & 1.7743 & .0794 & -.0155 & .2744 \\
\hline
\end{tabular}

\section{OUTCOME VARIABLE:}

welfc

Model Summary

\begin{tabular}{lcccccccc} 
& $\mathrm{R}$ & $\mathrm{R}-\mathrm{sq}$ & \multicolumn{1}{c}{ MSE } & $\mathrm{F}$ & $\mathrm{df1}$ & $\mathrm{df} 2$ & $\mathrm{p}$ \\
& .5879 & .3456 & .3014 & 48.5841 & 1.0000 & 92.0000 & .0000 \\
Model & & & & & & & & \\
& coeff & & $\mathrm{se}$ & $\mathrm{t}$ & $\mathrm{p}$ & $\mathrm{LLCI}$ & $\mathrm{ULCI}$ \\
constant & 1.7355 & .2055 & 8.4467 & .0000 & 1.3274 & 2.1436 \\
Retpol & .5375 & .0771 & 6.9702 & .0000 & .3844 & .6907 \\
$* * * * * * * * * * * * *$ & TOTAL, DIRECT, AND INDIRECT EFFECTS OF X ON Y ********
\end{tabular}

Total effect of $\mathrm{X}$ on $\mathrm{Y}$

$\begin{array}{lccccccc}\text { Effect } & \mathrm{se} & \mathrm{t} & \mathrm{p} & \text { LLCI } & \text { ULCI } & \text { c_ps } & \text { c_cs } \\ .5375 & .0771 & 6.9702 & .0000 & .3844 & .6907 & .7964 & .5879\end{array}$

\section{Direct effect of $\mathrm{X}$ on $\mathrm{Y}$}

$\begin{array}{lccccccc}\text { Effect } & \mathrm{se} & \mathrm{t} & \mathrm{p} & \text { LLCI } & \text { ULCI } & \mathrm{c}^{\prime} \_\mathrm{ps} & \mathrm{c}^{\prime} \_\mathrm{cs} \\ .4666 & .0861 & 5.4202 & .0000 & .2956 & .6376 & .6912 & .5103\end{array}$

Indirect effect(s) of $\mathrm{X}$ on $\mathrm{Y}$ :

$\begin{array}{ccccc} & \text { Effect } & \text { BootSE } & \text { BootLLCI } & \text { BootULCI } \\ \text { polimp } & .0709 & .0412 & .0063 & .1672\end{array}$

Partially standardized indirect effect(s) of X on Y:

$\begin{array}{lcccc} & \text { Effect } & \text { BootSE } & \text { BootLLCI } & \text { BootULCI } \\ \text { polimp } & .1051 & .0582 & .0098 & .2389\end{array}$

Completely standardized indirect effect(s) of $\mathrm{X}$ on $\mathrm{Y}$ : Effect BootSE BootLLCI BootULCI

$\begin{array}{lllll}\text { polimp } & .0776 & .0429 & .0072 & .1757\end{array}$

Level of confidence for all confidence intervals in output: 95.0000

Number of samples for percentile bootstrap confidence intervals: 5000 


\section{Interpretation of the results of mediation output}

The above results give facts in line with the three hypotheses that were developed for this study. The first hypothesis (H1) stated that "The Retirement Policy (X) has a significant and positive effect on Implementation (Y)." The effect of retirement policy on implementation was a coefficient. $=0.5480$; the t-value $=5.0307$; and $\mathrm{p}<0.01$. This meant retirement policy has a significant effect on implementation which is the mediator variable. This statistic upholds the first hypothesis (H1) that that "The Retirement Policy (X) has a significant and positive effect on Implementation (M)".

Regarding the second hypothesis (H2), "There is a significant positive of effect of implementation on welfare of retired clergy". The results yielded were coefficient $=0.1295$; $\mathrm{t}$-value $=1.7743$ which is below the $\mathrm{z}$-score of 1.96. This $\mathrm{z}$-score corresponds with $p<0.05$ significance. In this case it was $p>0.05$ as revealed by $p=0.0794$. This meant that the second hypothesis $(\mathrm{H} 2)$ was not fully attained because it was only positive and not statistically significant.

The third hypothesis (H3) "Implementation (M) mediates the relationship between retirement policy (X) and welfare (Y) of retired clergy" required computation and analysis of the mediation. This was intended to determine how much of the relationship between retirement policy and welfare operated indirectly through implementation. The results revealed that the total direct effect of retirement policy on welfare 0.5375; and the total indirect effect was 0.0709 with bootstrapping being 0.0063 (lower) and 0.1672 (upper) which did not imply clear significance. When the total indirect effect of 0.0709 was divided by the total direct effect of 0.5375 , it yielded 0.1319 or only $13 \%$ mediation effect. This implied that $13 \%$ of the relationship between retirement policy and welfare of retired clergy was explained indirectly or depended on the implementation approaches of the dioceses. The remaining $87 \%$ of the relationship operated directly.

\section{DISCUSSION}

The implementation of the retirement policy was being carried out by individual dioceses in Buganda Anglican ecclesiastical jurisdiction. In the Church of Uganda retirement policy clergy are required to retire at the clocking of 65 years of age. This retirement age applies to all clergy regardless of the level. That is, whether parish vicars, archdeacons, deans, bishops and archbishops all have one retirement age.

The retirement policy state that every retiring staff is entitled to arrears, gratuity and pension. However, the policy does not explicitly state how the dioceses ought to implement the policy. For that matter, each diocese set up its own implementation procedures. This is clearly illustrated in the table 6 .

Table-6: Terminal benefits per diocese

\begin{tabular}{|l|l|l|l|l|l|l|}
\hline & Mukono & Kampala & Luweero & Mityana & West Buganda & Namirembe \\
\hline Pension for Bishop & 125,000 & 500,000 & 125,000 & 200,000 & 250,000 & 125,000 \\
\hline NSSF for bishop & Paid & paid & no & Paid & paid & Paid \\
\hline Pension of Dean & 80,000 & 460,000 & 50,000 & 50,000 & 70,000 & 180,000 \\
\hline Pension of archdeacon & 80,000 & 460,000 & 50,000 & 50,000 & 100,000 & 180,000 \\
\hline Pension of Vicar & 60,000 & 400,000 & 50,000 & 50,000 & 76,000 & 150,000 \\
\hline Gratuity & Nil & paid & 600,000 & Nil & nil & Nil \\
\hline Gifts in Kind & Yes & yes & yes & Yes & yes & Yes \\
\hline
\end{tabular}

As it can be seen form table 6 , it is clear that there are variances in the implementation of the retirement policy. Some dioceses make contributions to the National Social Security Fund (NSSF) for their bishops while others like Luwero and West Buganda do not. The diocese of West Buganda instead of the NSSF have a diocesan provident fund. The diocese of Luwero does not pay NSSF but pays gratuity of UGX600, 000. The other dioceses do not give out gratuity. Some dioceses pay the same amount regardless of the level of the clergy, while others pay pension depending on the level of the clergy. However, in most if not all the dioceses put a Dean of the Cathedral on the level with the archdeacon.

The gift in kind given out to retiring clergy have included the following: vehicle, iron sheets, other building materials, plot of land, heads of cattle, gift on cash, heifer and others. These gifts in kind were given to most retiring clergy including bishops. Some gifts are given by parishes while others are given by the dioceses. The gifts vary in number, amount and size. The key gifts in kind have been retirement homes and vehicles where retiring clergy who received were $57 \%$ and $40 \%$ respectively. The remaining $3 \%$ account for the others. These gifts contribute the welfare of the clergy if properly implemented by a particular diocese.

It was further revealed that where retired clergy often ate all the meals every day, had access to clean and safe water, afforded electricity and possessed a personal home. Results also showed that the retired clergy sometimes have a TV at their homes, could afford medical expenses and made use of a telephone in 
addition to sometimes owning a car. The retired clergy sometimes make offertories in church every Sunday.

Although each diocese had some implementation approach it had adopted, some of the dioceses were not prompt in remittance of stated retirement benefits according to policy provisions. Given the above discussion, it was therefore necessary to analyse the mediation of implementation on the relationship between retirement policy and welfare of retired clergy.

The findings are in agreement with Mercer [37]; Amaike [38]; and Obashoro [39] who contended that when retirement policies were poorly implemented. For instance, they are inadequately funded, which resulted in both a drop in the living standards of the retired people and complications that directly threatened standards of living. This is because retirees were expected to depend mainly on their retirement benefits after working. They advised that there should be measures to ensure effective implementation of retirement policies so as to realize welfare among the retirees. This is supported by the mediation role of only $13 \%$ as exposed by the current study.

\section{CONCLUSION}

Since the implementation of the retirement policy by the diocesan was not satisfactory, the current study proposes a centralizes framework of implementation. It is through this that a significant contribution on the welfare of retired clergy in Buganda Dioceses can be achieved.

The study therefore recommends a revision of retirement policy by the Provincial assembly in order to incorporate provisions that shall facilitate effective implementation for improved welfare among the retired clergy. Furthermore, Diocesan Councils and the Diocesan Secretariats should encourage establishment of retirement offices and officers who should periodically provide progresses pertaining to the welfare of the retirees.

\section{REFERENCES}

1. Adenutsi DE. Retirement planning Conceptualization: challenges and policy options; 2011.

2. Church of Uganda Provincial Assembly Standing Committee Report; 2009.

3. Church of Uganda Provincial Human Resource policy Manual; 2009.

4. Church of Uganda Service Review Commission Report; 1978.

5. Mukono Diocese House of Clergy Report, Mukono. Church of Uganda; 2012.

6. Namirembe Diocese salary Circular, Kampala. Church of Uganda; 2016.

7. Luweero Diocesan Board of Finance Report; 2018.
8. Mbabazize PM. The Anglican Church In A Bid To Raise Income Among The Clergy And The Laity So As To Contribute To Their Livelihood And Acquire A Sustainable; 1994.

9. Ntagali S. Archbishop's Report to the House of Bishops, Church of Uganda; 2019.

10. Bukenya KDE and Ebitu OC. Retired Bishops and their wives Report, Church of Uganda.2017.

11. Namirembe Diocese Financial Guidelines, Kampala. Church of Uganda; 2015.

12. Mityana Diocese Financial Report, Mityana. Church of Uganda; 2018.

13. Mukono Diocese House of Clergy Report, Mukono. Church of Uganda; 2012.

14. Kazimba, S. Archbishop and the Bishop of Kampala Enthronement charge All Saints Cathedral Nakasero; 2020.

15. Rohwedder S and Willis RJ. Mental Retirement. Journal of Economic Perspectives. 2010; 24(1), 119-38.

16. Kalwij A and Vermeulen F. Health and Labour Force Participation of Older People in Europe: What Do Objective Health Indicators Add To The Analysis? Health Econ. 2008; 17(5):619-638.

17. Kenny GP, Yardley JE, and Martineau L and Jay O. Physical Work Capacity in Older Adults: Implications for the Aging Worker. Am J Ind Med. 2008; 51(8):610-625.

18. Silverstein M. Meeting the Challenges of an Aging Workforce. Am J Ind Med. 2008; 280(51):269-80

19. Asakawa K and Senthilselvan A. Trajectories of Health-Related Quality of Life Differ by Age Among Adults: Results From an Eight-Year Longitudinal Study. J Health Econ. 2012; 31(1):207-218.

20. Van Kippersluis H, Van Ourti T, O’Donnell O and Van Doorslaer E. Health and Income across the Life Cycle and Generations in Europe. J Health Econ. 2009; 28:818-830.

21. Ng TW and Feldman DC. A meta-analysis of the relationships of age and tenure with innovationrelated behavior. Journal of occupational and organizational psychology. 2013; 86(4), 585-616.

22. De Nardi M, Frenche and Jonesj B. "Medicaid Insurance in Old Age" (Working Paper No. 2013; 19151, NBER)

23. Kopecky KA and Koreshkova T. "The Impact of Medical and Nursing Home Expenses on Savings". American Economic Journal: Macroeconomics. 2014; 6(3), 29- 72

24. Anderson C. Human Resources Policies and Procedures Manual Bizmanualz. 2014.

25. Hyde $M$ and Jones IR. The Long Shadow Of Work-Does Time Since Labour Market Exit Affect The Association Between Socioeconomic Position And Health In A Post-Working Population. J Epidemiol Community Health; 2007; 61:533e539

26. Olesen K, Rod NH, Madsen IE, Bonde JP and Rugulies R. Does retirement reduce the risk of 
mental disorders? A national registry-linkage study of treatment for mental disorders before and after retirement of 245082 Danish residents. Occup Environ Med. 2015; 72(5), 366-372.

27. Wahrendorf M, Sembajwe G, Zins M, Berkman L, Goldberg M and Siegrist J. Long-term Effects of Psychosocial Work Stress in Midlife on Health Functioning after Labor Market Exit-Results from the GAZEL study. J Gerontol B Psychol Sci Soc Sci. 2012; 67:471e480

28. Schwingel A, Niti MM, Tang $\mathrm{C}$ and $\mathrm{Ng} \mathrm{TP}$. Continued Work Employment and Volunteerism and Mental Well-Being of Older Adults: Singapore Longitudinal Ageing Studies. Age Ageing. 2009; 38(5):531-7.

29. Sugihara $Y$, Sugisawa H, Shibata $H$ and Harada K. Productive Roles, Gender, and Depressive Symptoms: Evidence from a National Longitudinal Study of Late middle- aged Japanese. J Gerontol Ser B Psychol Sci Soc Sci. 2008; 63(4): P227-34.

30. Berkman LF, Kawachi I, Glymour MM, editors. Social epidemiology. Oxford University Press; 2014.

31. Thoits PA. Mechanisms linking social ties and support to physical and mental health. Journal of health and social behavior. 2011 Jun;52(2):145-61.
32. Hao Y. Productive activities and psychological well-being among older adults. The Journals of Gerontology Series B: Psychological Sciences and Social Sciences. 2008 Mar 1;63(2):S64-72.

33. Banks J, Chandola $\mathrm{T}$ and Matthews $\mathrm{K}$. International Encyclopedia of the Social \& Behavioral Sciences. Amsterdam: Elsevier; 2015.

34. Wang $M$ and Shi J. Psychological Research on Retirement. Annu Rev Psychol. 2014; 65:209-233.

35. Roscoe JT. The Fundamental Research Statistics for the Behavioral Sciences. $2^{\text {nd }}$ Edition. Holt, Rhinehart and Winston. New York; 1975.

36. Memon MA, Cheah JH, Ramayah T, Ting H, Chuah F. Mediation analysis issues and recommendations. Journal of Applied Structural Equation Modeling. 2018;2(1):1-9.

37. Mercer JH. An Idea Retirement System. 2015; [online] Retrived August 01, 2017 from https://www.mercer.com. Au /insights/focus. CFAmercer-ideal-retirement-system.html.

38. Amaike GO. Livelihood and Living Conditions of Formal Sector Retirees in Lagos State, Nigeria (Unpublished Ph.D. thesis). Department of Sociology and School of Postgraduate Studies, University of Lagos, Nigeria; 2009.

39. Obashoro O. Ageing Gracefully. Lagos, Nigeria: Concept Publications; 2010. 